\title{
How do pastoral families combine livestock herds with other livelihood security means to survive? The case of the Ferlo area in Senegal
}

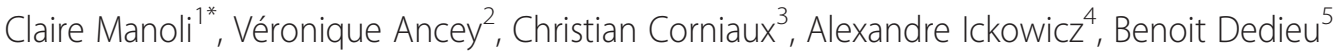 \\ and Charles Henri Moulin ${ }^{6}$
}

\begin{abstract}
Reducing vulnerability to hazards is a major challenge for pastoral settlements in the dry lands of sub-Saharan Africa. Accumulation of a stock of living animals is a major means of livelihood security that pastoralists use to cope with their constraints, amongst which is high environmental variability. Diversification and long-distance mobility are other means of livelihood security, implying specific family organization. We analysed the combination of these means in ensuring the livelihood security of 508 familial settlements in the rural community of Ferlo, Tessekre (Senegal). At least $40 \%$ of the settlements surveyed were small pastoral families, composed of one or two households with small herds (less than 50 cows and 50 sheep). Herds were the major means of livelihood security, but due to lack of a sufficient labour and other assets, the situation of these impoverished families was very precarious. In $28 \%$ of the settlements, families combined livestock, crops and non-farming activities as livelihood means. The remaining $32 \%$ of the settlements were pastoral settlements supported by large cattle herds and, in many cases, the production of Aïd el Kebir rams (for the major Muslim religious event). Non-farming activities were also present in these settlements with large herds, especially activities in the livestock trade. Diversification can reinforce the function of herds as savings accounts and might also enable the pastoralists to invest in livestock activities. There were three groups of settlements based on the characterization of livelihood security strategies used by pastoral herders. Over time, pastoralists have to utilize several means of security to cope with climatic shocks such as droughts, and familial events such as the death of the familial chief. Family organization (dispersal or grouping), diversification and mobility are important means used to recover after major losses of animals.
\end{abstract}

Keywords: Pastoralism; Diversification; Mobility; Security; Settlements

\section{Background}

Vulnerability and livelihood security are major challenges for pastoral livestock production systems in sub-Saharan countries, where the environment is highly variable (Ayantunde et al. 2011) and public policies do not guarantee social welfare. The concepts of vulnerability and livelihood security have been defined by their socioeconomic dimensions in livelihood studies (Swift 2006; Dehaan and Zoomers 2005; Chambers 2006). 'Vulnerability [...] refers to exposure to contingencies and stress, and difficulty in coping with them. Vulnerability has thus two sides: an

\footnotetext{
* Correspondence: c.manoli@groupe-esa.com

${ }^{1}$ Animal Production Department, Groupe ESA, 55 rue Rabelais, Angers Cedex 49007, France

Full list of author information is available at the end of the article
}

external side of risks, shocks, and stress to which an individual or household is subject; and an internal side which is defencelessness, meaning a lack of means to cope with damaging loss' (Chambers 2006).

Livelihood security means are defined here as livelihood strategies of the different methods used by pastoralists within their social and ecological context to cope with damaging losses. Herds are at the centre of pastoral lives and livelihoods. They have numerous functions, and one of them is to be utilized in the same way as stocks; therefore, they are a major means of livelihood security for pastoral families (e.g. Alary et al. 2011). Herds, especially bovine herds, are living capital used as savings accounts (Siegmund-Schultze et al. 2011). Stock is accumulated during good years to be able to destock

\section{它}


before and during severe droughts (e.g. Scoones 1995; McPeak and Barrett 2001).

Mobility of the herds through nomadism and transhumance is well known as a strategy to maintain herd survival and production when local resources are lacking (Ly et al. 2010). Mobility is also a strategy to utilize other than local resources (Schareika 2003). However, herds are not the only means of livelihood security. Diversification towards crops or non-farming activities (Bonfiglioli 1990; Adriansen 2006; Thornton et al. 2007) and the mobility of people driven by the need for new activities are additional ways to secure pastoral families (De Haan et al. 2002). Family gifts and contracts of living animals are traditional social insurances and constitute further security means related to family structure and relationships (Bonfiglioli 1988; Van Dijk 1994). Moreover, the families organized in settlements have different ways to manage their herds, from individual to collective managements, so there is the possibility of modifying the workforce and management structure as labour or economic needs evolve. This flexibility in labour and management allocation is considered another means of livelihood security for settlements (Corniaux et al. 2006; Ancey et al. 2007; Wane et al. 2009).

In pastoral areas, herders have numerous challenges that can transform the use of these 'traditional' means of livelihood security, including land tenure competition for agriculture, new trends in animal product markets due to growing urban demand, climatic changes and demographic pressures. For this study, we consider livelihood security an objective for pastoral settlements and that the different means of security used by pastoral herders may be changing due to these trends. Our central research question concerns the current contribution of the herds, constituting stocks, to livelihood security of the pastoral settlements in a dry land area in northeastern Senegal. Is the herd an effective means of ensuring the livelihood security of most pastoral settlements? How have pastoral settlements combined livestock with other means of livelihood security, such as (i) diversification of household income sources, (ii) long-distance mobility for the herds or for diversification purposes and (iii) changes in familial organization, from individual to more collective organizations? We address these issues with (i) an analysis of the current combination of livelihood security means and (ii) a more dynamic analysis of livelihood security means used in the past by herders to cope with external shocks and changes. We will also discuss the links between the livelihood security strategies used presently and herd management. We conclude with scientific perspectives and implications for policies.

\section{Study area}

This study was carried out in the rural community of Tessekre, in the pastoral reserve of Ferlo in Senegal (see
Figure 1). The climate in this area is Sahelian with little precipitation (less than $500 \mathrm{~mm}$ per year). One year is composed of a rainy season (two months) and a dry season (10 months). During the dry season, herds must be mobile to find pastures. The Sahelian climate is also characterized by severe decennial droughts that generally result in herd movements of greater distances.

The pastoral herds of Ferlo represent at least 25\% of Senegalese herd stocks in cattle, sheep and goats (Cesaro et al. 2010). Livestock production systems are based on the use of rangeland resources and involve a pastoral lifestyle. Pastoralists in this area predominately belong to Fulani communities. The area is structured around boreholes situated every $30 \mathrm{~km}$, built in the 1950s and 1960s. The rural community of Tessekre includes three boreholes. Inside each borehole area, pastoral families live in semi-sedentary settlements using different pasture sites throughout the dry season (Adriansen 2006). A settlement is a residential unit of a family group, organized into one or multiple houses (galle in Fulani). Each galle is a relatively autonomous centre of decision-making with one house chief. For example, when two brothers live together in a settlement, the settlements will be composed of two galle. Each galle can be composed of several households (hirande in Fulani), which are the units of consumption. For example, when a house chief has several wives, his galle will be composed of several households. The settlement is the unit of management of one cattle herd. The sheep and goat flocks are managed at the galle or household level (Corniaux et al. 2006; Wane et al. 2009). The pastoral settlements may also organize long-distance transhumance, engaging parts of the livestock and of the family, going from $50 \mathrm{~km}$ inside the Ferlo area to hundreds of kilometres towards agricultural areas in the south, such as Saloum (Dia 2009). In this study, the familial group organized around a single cattle group will be referred to as a settlement.

\section{Methods}

\section{Sampling}

A survey of the 582 settlements located in the area of the three boreholes was made in 2009. The data from the 582 settlements were used for two purposes. First, a multivariate analysis was made to examine the diversity of Tessekre's population. This multivariate analysis was made on a restricted sample of 508 settlements with complete and consistent data $^{\text {a }}$ (i.e. $86 \%$ of the total population). Second, a restricted sample of 16 settlements was used for a more in-depth diachronic analysis of how settlements combined different means of security over several decades. This restricted sample was representative of the diversity of settlements, and it was diversified for six criteria: nature of activities, herd size, species composition, family structure, 


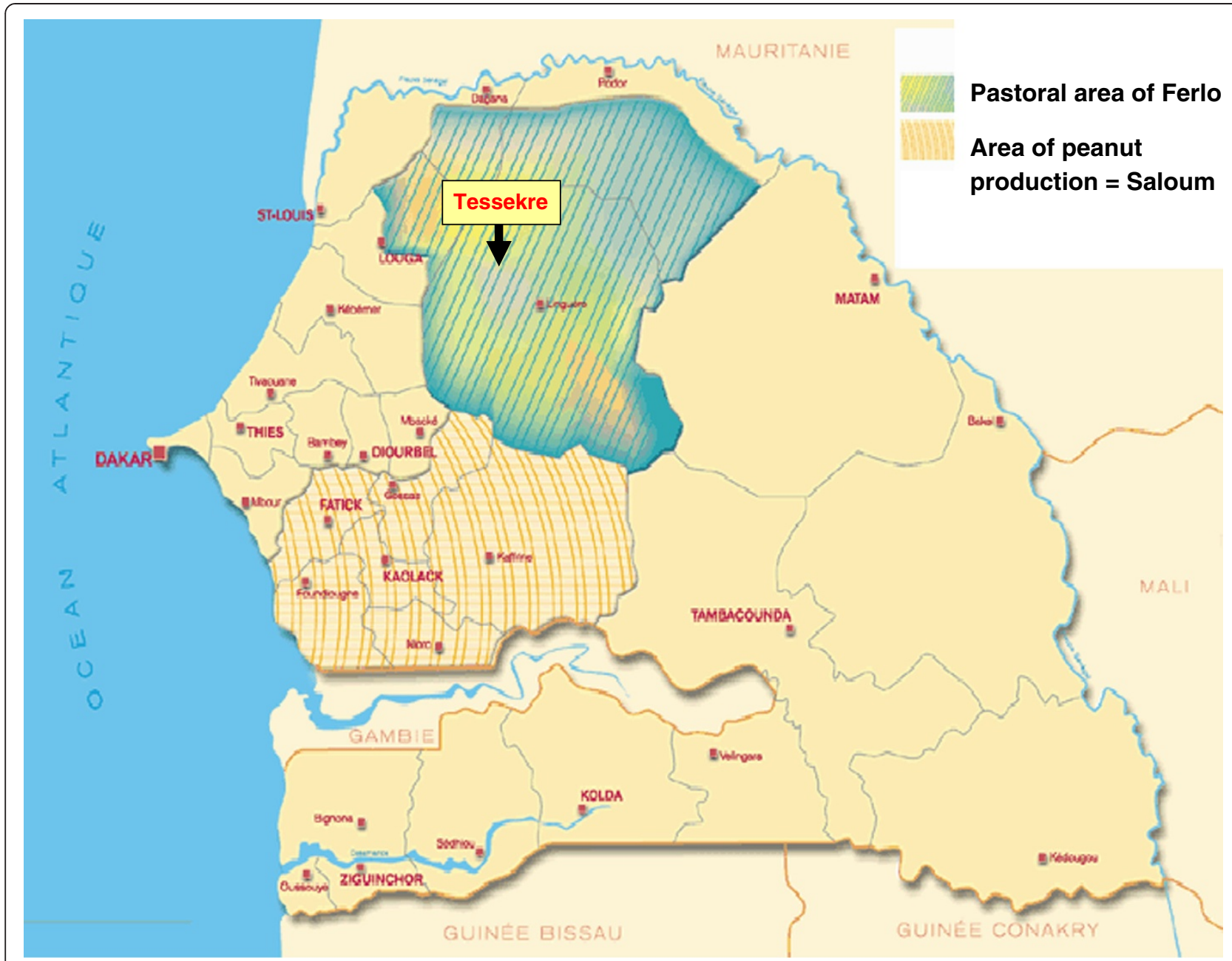

Figure 1 Map of Senegal (ref: PAPEL, Senegal). Destinations of transhumance are predominately in the southern part of Saloum.

regime of mobility and borehole location. Settlements from the three different groups identified in the first analysis were present in this restricted sample.

\section{Data collection}

For the comprehensive survey of 582 settlements, the objective was to obtain general qualitative data about the family, the herds and other activities. These data were collected during short interviews during the dry season of 2009.

For the in-depth survey of 16 settlements, two visits were made to each settlement during the dry season of 2010, with a stay of at least 24 hours for the first visit. Semi-structured interviews were carried out with several members of the family to improve the reliability of historical reconstruction, in line with the qualitative methods proposed by (Kaufman 1996), De Sardan (2003) and Bertaux (1997). Informal discussions and observations on the life of the settlement completed the data collection and improved the reliability of the information gathered.
Interviews focused on the evolution of several elements: settlement composition, management organization, the nature and division of activities in the settlement, herd size, the composition of species, mobility and sales practices. Various crises and events that occurred in the settlement since the 1970s were reconstructed, including decennial droughts (one of the major perturbations for pastoral activities in the Sahel) (Thébaud 2002) and other climatic crises and family events. The drought of 1973 was a starting point for trajectories and a common reference.

\section{Data analysis}

From the comprehensive survey, six qualitative variables were selected relating to the means of livelihood security (Table 1). For a multiple component analysis (MCA), a data subset of 508 settlements was used. We used the first seven factors with an eigenvalue greater than 0.15 to calculate the squared Euclidean distance between each settlement and to make a hierarchical cluster analysis (HCA) with the Ward aggregation method to establish a 
Table 1 Variables and their modalities used for MCA data subset of 508 settlements

\begin{tabular}{ll}
\hline Variables & Modalities \\
\hline No. of households & 1 or 2 \\
& 3 or 4 \\
& 5 and more \\
No. of cattle & None \\
& $<20$ \\
& 20 to 50 \\
& $>50$ \\
No. of small ruminants & 20 to 100 \\
Crops & $>100$ \\
Non-farming activities & Yes \\
& No \\
Long-distance mobility & Yes \\
& No \\
\hline
\end{tabular}

typology of the settlements. The multivariate analyses were performed with the FactoMineR and ADE4 packages of the R 2.12.0 software ( $R$ Development Core Team 2011).

Data from surveys of 16 settlements were organized through a depiction of the settlement trajectories, activities and herds (Moulin et al. 2008) to identify the levels of animal loss, from the point of view of the herders due to successive crises, and to identify which means of livelihood security were used to survive these crises and recover after major losses. Using this diachronic analysis, we identified 10 variables to describe a settlement's status during its current phase of the trajectory. Identification and implementation of these 10 variables were possible due to a closer understanding of the settlements' daily life observed during the 24-h visits to the settlements. Table 2 presents the 10 variables and the number of settlements in each modality. Using this information, we were able to describe more precisely the current livelihood security strategies for each group identified in the multivariate analysis. This allowed us to present a typology of present livelihood strategies in current settlements.

\section{Results}

The current diversity of pastoral settlements in the rural community of Tessekre

The observed settlements housed mostly small families with one or two households (59\%) (Table 3). Specialization towards pastoral activity was still very strong; crops were declared by only $24 \%$ of the settlements and non-farming activities by $32 \%$. Most of the settlement families breed cattle and small ruminants, and only $7 \%$ do not breed cattle. We characterized the settlements into three groups based on their attributes. Settlements in group A were the smallest settlements with the smallest herds. They did not have additional agricultural activities but did practise other non-farming activities. They represented $40 \%$ of the 508 settlements. Because they were the smallest settlements with the smallest cattle herds, we can infer that they are the most impoverished pastoralists. In group $\mathrm{B}$, the settlements were more agropastoral. They were small- to mediumsized settlements with variable stocks in cattle or small ruminants. This is the only group that included pastoralists without any cattle. They represented $28 \%$ of the 508 settlements.

The largest settlements with the largest herds of cattle and small ruminants were in group C. Some had other non-farming activities, including crops, but the majority did not practise crop-based agriculture. They represented $31 \%$ of the 508 settlements.

\section{The diversity of current livelihood strategies}

We conducted an analysis of the current livelihood strategies for each of the three identified groups for the 16 families surveyed. For group C, we detailed sub-category strategies, designated C1, C2 and C3 (Table 4).

Settlements in group A were small pastoral settlements with small herds that they were attempting to increase. The stock, fewer than 100 goats and sheep and fewer than 20 cattle, was the main income source. The small workforce was dedicated to livestock husbandry, and only short lengths of time could be allocated to occasional non-farming activities to increase income. These occasional activities included working as paid herdsmen, small retail traders and middle men, called 'tefanke, for the livestock trade. Livestock was the main means of livelihood security, but the settlements were very precarious due to the small numbers of stock. Lack of other income sources leads to large reductions in stock, possibly even more than the annual growth of the herd. The goal of increasing the stock in this situation is difficult to accomplish.

Settlements of group B, using data gathered during indepth visits, were agropastoral settlements maintaining medium-sized herds, along with crops and other nonfarming activities. For these settlements, the crop growing was an important activity, complemented with raising livestock and other non-farming activities. They grew primarily peanuts, millet and black-eyed peas ('niebe') and, in some cases, watermelon. Occasionally, the peanut crop was sold, but for the most part, these crops and crop residues were used for human consumption and as animal feed. Similar to group A, the numbers of stock were low for all species, but in this group, 
Table 2 Ten qualitative variables assessing security strategies of pastoral settlements and number of settlements for each modality of variables $(n=16$ settlements, 2010)

Variables Modalities of variables $\begin{gathered}\text { No. of } \\ \text { settlements }\end{gathered}$

Family organization

$\begin{array}{lll}\text { No. of houses (galle) } & 1 & 11 \\ & 2 & 3 \\ & >2 & 2 \\ \text { No. of households } & 1 \text { or } 2 & 6 \\ \text { (hirande) } & 3 \text { or } 4 & 8 \\ & 5 \text { and more } & 2 \\ \text { No. of adults } & <5 & 5 \\ & 5 \text { to } 15 & 5 \\ & 16 \text { and more } & 6\end{array}$

Diversification

\begin{tabular}{|c|c|}
\hline \multirow[t]{4}{*}{ Type of activities } & Livestock farming only \\
\hline & $\begin{array}{l}\text { Livestock farming and } \\
\text { occasional non-farming } \\
\text { activities }\end{array}$ \\
\hline & $\begin{array}{l}\text { Livestock and non-farming } \\
\text { activities }\end{array}$ \\
\hline & $\begin{array}{l}\text { Livestock farming and crops } \\
\text { and non-farming activities }\end{array}$ \\
\hline \multirow{3}{*}{$\begin{array}{l}\text { Presence of livestock } \\
\text { market operators }\end{array}$} & No \\
\hline & Market intermediary (tefanke \\
\hline & Livestock trader (dioula) \\
\hline \multirow{3}{*}{$\begin{array}{l}\text { Activity of ram sales } \\
\text { for the Tabaski }\end{array}$} & No \\
\hline & Opportunistic sales \\
\hline & $\begin{array}{l}\text { Sale of large batches, more } \\
\text { than } 60 \text { rams per year }\end{array}$ \\
\hline
\end{tabular}

Accumulation of stock

$\begin{array}{ll}\text { No. of small ruminants } & <100 \\ & 100 \text { to } 300 \\ & >300 \\ & 0 \\ \text { No. of cattle } & 1 \text { to } 20 \\ & 21 \text { to } 50 \\ & 51 \text { and more }\end{array}$

Mobility

Long-distance mobility No to Saloum

Mobility of a part of the herds and family

Mobility of all the herds and family
Table 2 Ten qualitative variables assessing security strategies of pastoral settlements and number of settlements for each modality of variables $(n=16$ settlements, 2010) (Continued)

\begin{tabular}{lll}
\hline $\begin{array}{l}\text { Frequency of non-local } \\
\text { activities }\end{array}$ & 7 \\
& $\begin{array}{l}\text { Occasional (less than } \\
\text { one week per month) } \\
\\
\text { Regular (more than one week } \\
\text { per month) }\end{array}$ & 5 \\
\hline Tabaski is the local name for the Aid el Kebir ceremony.
\end{tabular}

numbers were also very low for cattle. Herds had not been reconstructed after recent losses. However, issues of livelihood security depending on the herds were not as pressing, because income was available from other activities. Settlement families interviewed during the indepth visits were only in large settlements with a collective organization of their workforce. For this group, an opportunistic orientation towards Tabaski rams was possible.

Table 3 Distribution (in number) of 508 surveyed settlements within three identified groups and distribution (in percentage) of settlements of a group within modalities of each variable used for multivariate analyses

\begin{tabular}{|c|c|c|c|c|}
\hline \multirow[t]{2}{*}{ Settlement groups } & \multirow{2}{*}{$\begin{array}{c}\text { A } \\
\text { Small } \\
\text { herds }\end{array}$} & \multirow{2}{*}{$\begin{array}{c}\text { B } \\
\text { Medium } \\
\text { herds }\end{array}$} & \multirow{2}{*}{$\begin{array}{c}\text { C } \\
\text { Largest } \\
\text { herds }\end{array}$} & \multirow[t]{2}{*}{ Total } \\
\hline & & & & \\
\hline $\begin{array}{l}\text { No. of settlements in } \\
\text { each group }\end{array}$ & 207 & 142 & 159 & 508 \\
\hline \multicolumn{5}{|l|}{ No. of households } \\
\hline 1 or 2 & 74 & 69 & 31 & 59 \\
\hline 3 or 4 & 26 & 31 & 36 & 31 \\
\hline 5 and more & 0 & 0 & 32 & 10 \\
\hline \multicolumn{5}{|l|}{ No. of cattle } \\
\hline None & 0 & 27 & 0 & 7 \\
\hline$<20$ & 44 & 30 & 13 & 30 \\
\hline 20 to 50 & 56 & 28 & 9 & 34 \\
\hline$>50$ & 0 & 15 & 77 & 29 \\
\hline \multicolumn{5}{|l|}{ No. of small ruminants } \\
\hline 20 to 100 & 58 & 54 & 13 & 43 \\
\hline$>100$ & 42 & 46 & 87 & 57 \\
\hline \multicolumn{5}{|l|}{ Crops } \\
\hline Yes $^{a}$ & 0 & 82 & 4 & 24 \\
\hline \multicolumn{5}{|l|}{ Non-farming activities } \\
\hline$Y_{e s}^{a}$ & 34 & 27 & 33 & 32 \\
\hline \multicolumn{5}{|l|}{ Long-distance mobility } \\
\hline$Y_{e s}^{a}$ & 29 & 24 & 31 & 29 \\
\hline
\end{tabular}

${ }^{\mathrm{a}}$ The other modality is No. 
Table 4 Livelihood security strategy for three groups, with 10 detailed variables used for in-depth analysis

\begin{tabular}{|c|c|c|c|c|c|}
\hline Security strategies & $\begin{array}{c}\text { A } \\
\text { Small herds }\end{array}$ & $\begin{array}{c}\text { B } \\
\text { Medium herds }\end{array}$ & $\begin{array}{c}\text { C1 } \\
\text { Large herds }\end{array}$ & $\begin{array}{c}\text { C2 } \\
\text { Large herds }\end{array}$ & $\begin{array}{c}\text { C3 } \\
\text { Large herds }\end{array}$ \\
\hline No. of settlements & 4 & 3 & 3 & 3 & 3 \\
\hline \multicolumn{6}{|l|}{ Familial organization } \\
\hline No. of houses & 1 & 2 & 1 & 1 & 2 \\
\hline No. of households & 1 & 5 & 2 & 3 & 4 \\
\hline No. of adults & 2 & 16 & 4 & 4 & 18 \\
\hline \multicolumn{6}{|l|}{ Diversification } \\
\hline Crops & - & Yes & - & - & - \\
\hline Non-farming activities & - & Yes & - & - & - \\
\hline Livestock trade & - & - & One trader & - & One trader \\
\hline Ram sales for Tabaski & - & Opportunistic & Opportunistic & Large batches & Large batches \\
\hline \multicolumn{6}{|l|}{ Accumulation of stock } \\
\hline No. of cattle & 0 & 7 & 30 & 80 & 50 \\
\hline No. of small ruminants & 35 & 185 & 200 & 300 & 350 \\
\hline \multicolumn{6}{|l|}{ Mobility } \\
\hline Transhumance to Saloum & - & - & - & Yes & - \\
\hline Non-local activities & Occasional & Regular & - & - & Regular \\
\hline
\end{tabular}

Values represent one typical settlement of each group.

TLUb/adults: 1.75 (A), 2.75 (B), 17.5 (C1), 35 (C2), 6.7 (C3).

Pastoral settlements supported by large herds constituted group C. These settlements took advantage of large numbers of livestock whose annual reproductive growth was utilized both in sales for consumption needs and in savings of live animals to reinforce livelihood security. Depending on the size of the family, some members of the settlements were engaged in other activities, such as the livestock trade. Management of large batches of rams sold for the Muslim celebration Aid el Kebir (called Tabaski in Senegal) was an additional way to generate income ${ }^{c}$. This activity relied on the supplemental purchase of young rams additional to animals in the family flock. This strategy was accompanied by greater annual productivity of the ewes, accomplished due to a long-distance transhumance to Saloum, where the availability of animal fodder is greater than in Ferlo. Settlements with a $\mathrm{C} 1$ strategy were small settlements focused on livestock farming and trade in live animals. When trade activity was present, at least one person in the settlement was engaged as a 'dioula' or livestock trader. Adults were few, and association between brothers was possible which increased the number of adults available for herd management. In the $\mathrm{C} 2$ strategy, medium-sized families were focused on livestock farming with an orientation towards raising large batches of rams to sell for Tabaski. In the C3 group, there were large-sized settlements with collective organization of several houses (galle). They managed a large cattle herd and several flocks of small ruminants. Sheep herds provided large batches of rams for
Tabaski. In this last case, the available workforce exceeded the needs for livestock farming. Therefore, some adults, i. e. the settlement chief or one of his brothers or older sons, were engaged in long-distance diversification activities or trade in live animals (dioula).

\section{How did the settlements use several security means in the past?}

Three different periods of drought during the last four decades have greatly affected the herds of the settlements (Figure 2). Among the 16 surveyed settlements, $85 \%$ of the settlements had major losses ${ }^{\mathrm{d}}$ of livestock due to the 1973 drought, and 60\% had major losses due to the 1984 drought. Dry periods during the 1990s and into the 2000s had fewer impacts, with only $20 \%$ of the settlements declaring major losses. The mobility of herds towards southern areas was a major means to cope with the lack of feed resources (Figure 2), especially for the 1984 drought, during which only $15 \%$ of the settlements did not move.

Nevertheless, since the 1980s, none of the settlements that chose to stay in the Ferlo area during dry years suffered major losses. They utilized other means to preserve their livestock, such as the purchase of supplementary feeds from the income of non-farming activities and/or the sale of animals. Gifts of supplementary feed for cattle by local NGOs based in Tessekre were also a way to save herds that did not move, especially during the 1984 drought. 


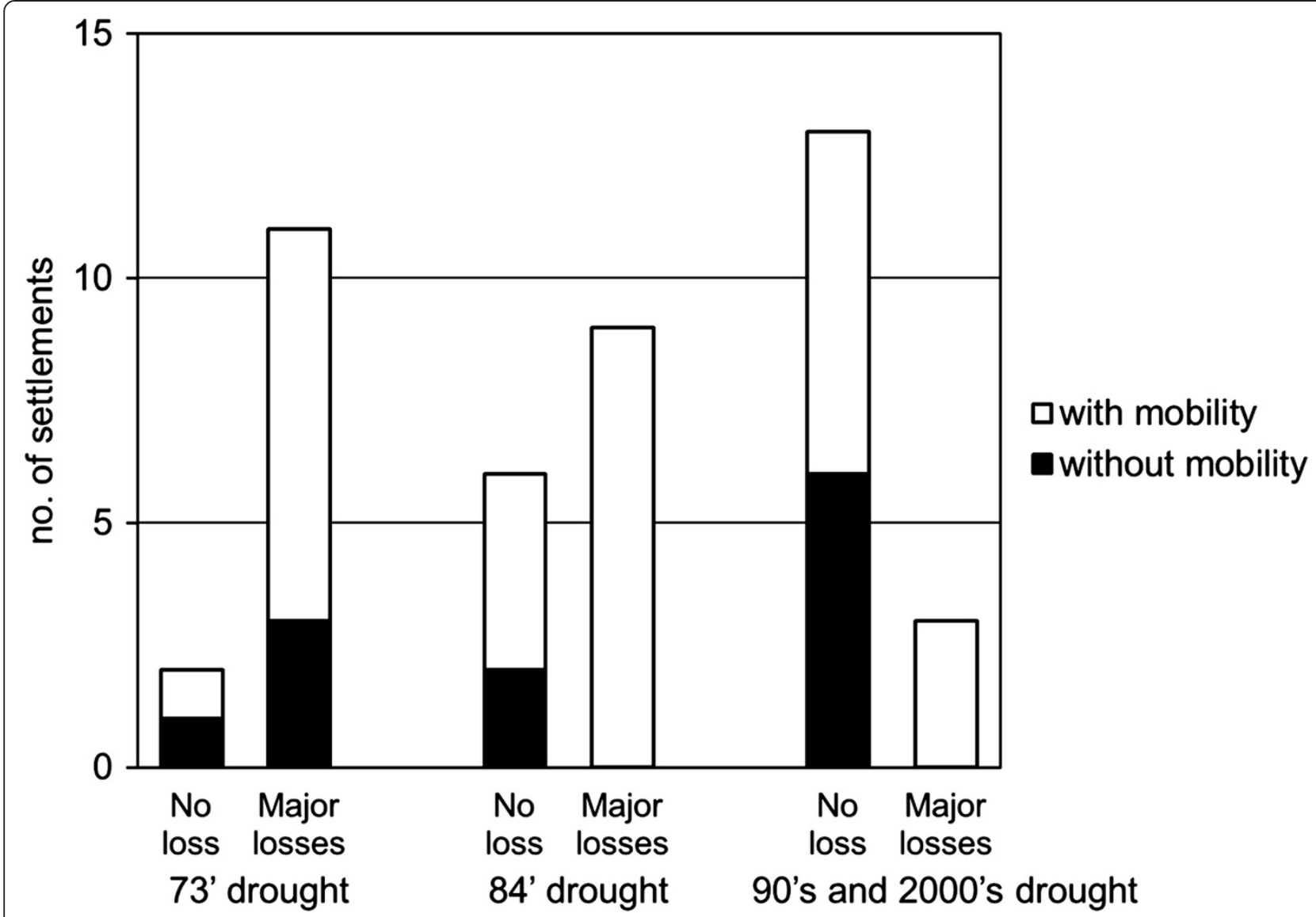

Figure 2 Number of settlements with/without major losses and use/no use of long-distance mobility. Data are available for three periods of drought with trajectories from a sample of 16 settlements. Data are available for 13 settlements for the 1973 drought and 15 settlements for the 1984 drought. A major loss is defined by a more than 25\% loss in herds of cattle and small ruminants.

After periods of drought and losses of animals, the settlements used three main strategies to survive. One strategy was that one or more members of the settlement developed a new diversification activity in the local area (10 occurrences) or at a long distance (3). Examples of these activities were employment at a sugar cane company near the Senegal River, working as salaried herdsman or in the livestock trade, and obtaining temporary jobs in local cities or in Dakar. A second strategy was to modify their familial organization (10) with dispersal of the settlement or regrouping into smaller settlements as a method to balance the number of workers, consumption needs of all persons and herd size. During dispersals, men of the settlements went to cities in search of new activities. Furthermore, they took advantage of a large stock of animals (11), keeping a sufficient number of animals even after a major loss to ensure the natural growth of the herd. This also enabled settlements to acquire cash and savings from livestock sales to assist in recovery.

Droughts or other external shocks, such as epizootic events and internal changes linked to the life cycle of the families, also drove the settlements to use new means of livelihood security during the 1990s and 2000s. Local (12) and long-distance (2) diversification was the main change observed in the settlement trajectories. Family organization (6) and taking advantage of large herds (6) were also observed. Five settlements began a new form of mobility, a regular long-distance move to Saloum. These results show that the settlements combined and adapted several means of livelihood security over time.

\section{Discussion}

A pastoral area with unequal livelihood security among settlements

Since we used two different methods of interviews in this study, we found uncovered different levels of reality. We applied a comprehensive survey with very short interviews and secondly, longer, more detailed interviews based on a restricted sample. In the first method, the declaration of non-farming activities could correspond to very different realities: non-farming activities could involve one or more members of the settlements, and it 
could have been current, seasonal or regular activities that were reported. These different responses could imply very different levels of importance of these activities for the income and survival of the settlement. Declarations related to the size of the herds were also sometimes unreliable. However, the comprehensive survey has given a representative insight into the pastoral family population in Tessekre. The issue of data reliability received from the initial short interviews could explain the apparent small differences noted between the groups $\mathrm{A}, \mathrm{B}$ and $\mathrm{C}$.

The combination of the short interviews with a more comprehensive approach made it possible to assess the rationale and the contribution of non-farming activities for each settlement surveyed. The contribution of nonfarming activities to income is still not quantified, but the importance of this contribution to the settlement is assessed with a qualitative approach. In the Sahelian context, even very small additional incomes can significantly contribute to the livelihood security of a settlement.

By combining these two approaches, it is possible to quantify the profiles in the total population of Tessekre. Group A represented the most precarious and impoverished group, group B represented other precarious settlements with low stocks of herds, and group $\mathrm{C}$ included the most stable settlements and the least impoverished.

This distribution of settlements reflects an inequality between pastoralists that is mainly linked with herd size. The mechanisms of redistribution and limitations on herd size reported in the literature (Schneider 1979) no longer seem strong enough or are no longer utilized in this rural community; this phenomenon was also previously stressed by Sutter (1987) for the 1980s.

\section{The Ferlo pastoral settlements are between specialization and diversification}

The situation of pastoral settlements in 2010 to 2011 in the Ferlo area could be characterized by the specialization in livestock activities and not in crops: the comprehensive survey reports that only $28 \%$ were agropastoralists. This is a peculiar situation compared with other pastoral areas of West Africa (Grégoire and Raynaut 1997), where agropastoralism is more developed. The colonial policy of installing pastoral boreholes beginning in the 1950s was favourable for livestock activities in Ferlo and, until now, has reinforced this pastoral specialization (Thébaud 1990). The small size of families in the settlements, with a majority $(60 \%)$ of settlements having only one or two households and $90 \%$ having a maximum of four households, is another remarkable finding. This is consistent with the general socioeconomic evolution in rural areas of West Africa, with the growing individualization of households replacing more complex family structures (Becker 1990; Chia et al. 2006), and with increased population density that has consequences on fragmentation of herds and of settlements.

Diversification through local and non-local activities is another major trend. The importance and influence of non-farming activities are quite different in the small impoverished pastoral settlements compared with the large pastoral settlements. For the small settlements, the shortage of labour is a constraint to developing strong non-farming activities, and the settlements must be opportunistic, only participating in non-farming activities during the months of the year when some member of the family can be spared from animal husbandry activities. This is a diversification for necessity (Ellis 2000). For the large pastoral settlements, diversification is more a matter of choice. Due to the larger workforce, some members of the settlement may not be heavily involved in livestock farming, and they can develop profitable non-farming activities, as described by Adriansen (2006, p. 225) who reported that 'within large households, family members can specialize in different ways. Thereby, household activities are diversified with a specialization at the individual level.'

A final important trend is the development of investment in sheep production due to the Tabaski product, as described by Wane et al. (2010). This seasonal product offers a major opportunity in this area and in the livestock sector of Senegal in general. Even if the sales occur only once a year, the value of animals during this period is so high that it is profitable to accumulate animals throughout the year to prepare for these annual sales. Examining the different groups, we conclude that accumulating batches of rams is possible only for economically secure groups. Income from sales of a batch of rams is reinvested to buy more rams for the next year or is used for large investments, such as the building of concrete huts. During the years 2010/2011, the Tabaski period was very favourable, as it occurred during November just after the end of the rainy season. Therefore, rams were already fat enough to be sold without very much finishing. When the Tabaski period occurs during the dry season, it is more difficult for herders to fatten their rams.

Additionally, the demand for Tabaski rams is increasing with the development of an urban middle class. The rams from Ferlo are considered suited to the middle class market (Ancey and Monas 2005), as they are small-sized rams. In Ferlo, the market for Tabaski rams is an opportunity to increase incomes for pastoral herders. This opportunity should be monitored closely in future years to determine if it remains a profitable activity for herders when Tabaski occurs during the dry season. 


\section{Livelihood security strategies and trajectories}

The analysis of trajectories showed that a settlement may have encountered several phases in recent decades and used multiple strategies during these phases. For group C, pastoral settlement based on herd accumulation, we noted that they required time to achieve stability. In the last four to five years, no family or climatic events have affected these settlements. Settlement chiefs are middle-aged men with sons or brothers old enough to take on responsibilities for herd management. Groups A and B were, in contrast, in more precarious phases of their trajectories: herds have undergone recent and consecutive losses after a severe event, e.g. droughts or accidental death of a family chief or herds, and settlements have been in a progressive decline or dispersal in recent years. Family chiefs are either young men with new responsibilities in herd management or very old men with no young successors to help them in herd management. This description is consistent with anthropological studies on the dynamics of residential units (Dupire 1996; Bonfiglioli 1988). Settlement dynamics result from crises experienced or the life cycles of individuals, such as the maturation of young men and the decline of old family chiefs. These familial events determine the means of livelihood security that pastoralist groups may choose to develop.

In this study, we focused on identifying livelihood security strategies, but we did not make a quantitative assessment of familial poverty. Our security assessment is based primarily on the analysis of herd stocks, i.e. the main asset for pastoralists. Little et al. (2011) agree that this is the most accurate way to qualify pastoralists' poverty. Our security assessment also shows the trajectories of climatic and familial events. Further research should be conducted to better assess the vulnerability of pastoral settlements, so as to distinguish between chronic and transitory poverty. Our survey did not contain enough data to assess whether settlements were caught in a permanent poverty trap or only temporarily poor. Flexibility in using different means to gain livelihood security is not the same for elders and younger individuals.

\section{The links between livelihood security profiles and herd management}

Each group has different levels of flexibility possible for herd management (breeding, feeding, watering practices, purchases and sales of animals). In group A, the relatively low productivity of cattle in the Sahelian context (the growth rate of herds is no more than $10 \%$ to $12 \%$ in Sahel; see Ba et al. 2011; Otte and Chilonda 2002) does not enable the families to remove a sufficient number of animals to fulfil their economic needs without endangering the renewal of the herd. After a major loss of animals, more than a decade is necessary to recover to the levels of the initial stock, supported by only natural growth rate (Lesnoff et al. 2012). The lack of access to other income sources to buy feed or veterinary products and the lack of labour beyond the imperative needs for watering are major constraints to productivity.

In group $\mathrm{C}$, the larger animal stocks, the availability of workforce and the possibility of gaining cash by selling some animals or from other income streams enable herders to better manage their cattle and small ruminants, increasing their productivity. Sheep are the most frequent target for this improvement, by changing breeds, from the local Peul-Peul breed to introduced breeds, such as Touabir (from Mauritania) or Bali-Bali (from Mali), by providing larger and heavier rams for market, and by herd mobility to Saloum to increase ewe productivity. The flows of income from animals contribute to family livelihoods and to providing urban markets with animal products.

In group $B$ in an agropastoral situation, the link between crops and livestock needs to be more thoroughly investigated in terms of biomass flows and competition for family labour.

\section{Future perspectives}

The first priority is to increase our understanding of the technical aspects of herd continuity. Nozieres et al. 2011 have listed no less than six sources of flexibility within herd management that could be further examined: for example, choices between productivity versus survival in herd feeding methods, or in the seasonal distribution of sales of different livestock species. In particular, the activity of Tabaski marketing is a crucial issue in current livestock development planning in Senegal, especially in the modalities of this activity, its interaction with the grain market and the agricultural calendar. These aspects could be examined in more detail.

The second priority concerns the definition of livelihood security. We have taken an original approach in analysing livelihood security strategies. However, existing livelihood analytical frameworks also consider other strategies and means of security in vulnerability assessments (Swift 2006; Ancey et al. 2009; DeHaan and Zoomers 2005), such as access to power in decision-making inside the settlements, exchanges of gifts and loans, and adherence to social networks. Further studies on pastoral livelihood security should expand to include these strategies not linked directly to herd management. For example, emerging strategies of young adults could be studied, e.g. their choice to participate in labour migration or activities that remove them from livestock activities and local pastoral life (Manoli and Ancey 2014).

\section{Conclusion}

This research has presented an overview of the diversity of livelihood means of security, strategies used by pastoral 
herders in a rural community, including diversification of activities, mobility of the herds and organization of the families in settlements. The main hardships that pastoralists face in the region studied are climatic shocks such as droughts, and familial events such as the death of the familial chief. We characterized three different groups in the population studied. Each group represents how a combination of several livelihood security means is used in different settlements. These three current groups of livelihood security strategies are ephemeral, and over time, the pastoralists have to use several different strategies to cope with climatic shocks and familial events.

Livestock farming remains the principal activity for pastoral settlements located in the rural community of Tessekre. Therefore, herds are still necessary for pastoral survival, but the security provided by herds is not always sufficient. After external shocks, such as droughts, or after events linked with the family life cycle, some settlements remain with few livestock, and due to the lack of family workforce, they cannot engage in diversification activities. They are therefore obliged to remove too many animals from their herds, thus preventing the recovery of their stock. The economic situation of these settlements, at least $40 \%$ of the population, is very precarious. Current pastoral social solidarity mechanisms seem unable to provide sufficient numbers of animals for these families. Poverty alleviation policies need to have focus on two situations: the end of the life cycle of the settlement, with the protection of the elders and the maturation of young householders.

When there are opportunities, pastoral settlements use other means of livelihood security in addition to their stocks of animals; diversification includes people and herds becoming more mobile. These means enable families to preserve a sufficient stock of animals or to quickly recover a herd. Non-farming activities, especially livestock trading, provide funds to prevent excess offtake from the herds in the event of crises and can also enable pastoralists to invest in livestock activities. Diversification increases the capacity of the herds to contribute to the security of the settlement and also enables pastoralists to increase herd productivity. In this case, pastoral livestock may better provide urban markets with animal products, without an increase in herd numbers, which is a crucial environmental issue.

\section{Endnotes}

${ }^{\text {a }}$ Settlements with incomplete data and settlements with data that were not consistent (e.g. herds declared to have less than 20 small ruminants) due to incorrect declarations of herders or mistakes in data entry were not used in this sample.

${ }^{\text {b}}$ Tropical livestock units (TLU) are calculated (adapted from Otte and Chilonda 2002) as follows: one cow $=1$
TLU, and one small ruminant $=0.2$ TLU. The ratio of TLU/adults represents the stock in relation to the labour force and consumption units, and it is therefore more appropriate than using the stock only to assess the poverty of a family.

${ }^{\mathrm{C}}$ Incomes from this Tabaski activity can be significant in this area (Manoli 2012) ranging from 10,000 to 85,000 FCFA for each ram, with 80 to 132 rams sold in one or more sales prior to the Muslim celebration. The price of one ram not sold for Tabaski is approximately 10,000 to 15,000 FCFA.

${ }^{\mathrm{d}}$ A major loss is defined as a loss of more than one third of the herd (in small ruminants or/and cattle).

\section{Competing interests}

The authors declare that they have no competing interests.

\section{Authors' contributions}

The work reported in this manuscript was a component of a wider doctorate study made by CM. BD and CHM were directors of the doctorate, Al, VA and $\mathrm{CC}$ were field supervisors. CHM has performed the multivariate analysis. BD, CHM, VA, CC and Al made substantial contributions to this work from conception of design study to advices for data collection, analysis, drafting and revising the manuscript. All authors read and approved the final manuscript.

\section{Authors' information}

CM was a PhD student in Montpellier University, for INRA and CIRAD institutions, and is now a livestock production systems teacher and researcher at the Agricultural School of Angers (Groupe ESA). VA is a socioeconomist, specialist of Sahelian pastoralism, and researcher at CIRAD, France. CC and Al are livestock production systems researchers and specialists of Sahelian pastoralism at CIRAD, France (AI) and Senegal (CC). BD is a livestock production systems researcher and specialist of work management and extensive livestock production systems, at the head of SAD Division, INRA, France. CHM is a livestock production systems researcher and teacher at Montpellier SupAgro (France) and a specialist of livestock production systems in Mediterranean and Sahelian countries.

\section{Acknowledgements}

This work has been funded by and conducted within the 'Livestock Climate and Society' project (ECLIS, ANR-AA-VULNS-003). Authors thank Ramata Cisse and Moustapha Dia for translation in Puular during fieldwork. They also thank members of the research team PPZS (Dakar, Senegal) for both logistical support and scientific advice, and Jane Curtis for reviewing the English. They also thank pastoral families for hospitality and tolerance during interviews.

\section{Author details}

'Animal Production Department, Groupe ESA, 55 rue Rabelais, Angers Cedex 49007, France. ${ }^{2}$ UMR ART-dev, CIRAD, rue Jean-François Breton, Montpellier Cedex 34398, France. ${ }^{3}$ UMR SELMET/ PPZS, CIRAD, Dakar Hann BP 2057, Senegal. ${ }^{4}$ UMR SELMET, CIRAD, Campus SupAgro La Gaillarde Bat 22, 2, PI., Viala, Montpellier 34060, France. ${ }^{5}$ SAD Division, INRA, Centre de Clermont-Theix, Saint-Genès-Champanelle 63122, France. ${ }^{6}$ UMR SELMET, Montpellier SupAgro, 2, pl. Viala, Montpellier 34060, France.

Received: 9 December 2013 Accepted: 28 February 2014 Published: 17 Mar 2014

\section{References}

Adriansen, HK. 2006. Continuity and change in pastoral livelihoods of Senegalese Fulanis. Agriculture and Human Values 23: 215-229.

Ancey, V, and G Monas. 2005. Le pastoralisme au Sénégal, entre politique "moderne" et gestion des risques par les pasteurs. Revue Tiers Monde 46: 761-783. 
Alary, V, C Corniaux, and D Gautier. 2011. Livestock's contribution to poverty alleviation: How to measure it? World Development 39: 1638-1648.

Ancey, V, A Ickowicz, C Manoli, and S Magnani. 2007. Liens entre troupeaux et familles chez les Peuls du Ferlo : indicateurs socio-économiques des mutations de l'élevage pastoral. In Quatorzièmes rencontres autour des recherches sur les ruminants, 185-188. Paris, France.

Ancey, V, A Ickowicz, I Touré, A Wane, and AT Diop. 2009. La vulnérabilité pastorale au Sahel: portée et limites des systèmes d'alerte basés sur des indicateurs. In L'élevage, richesse des pauvres: stratégies d'éleveurs et organisations sociales face aux risques dans les pays du Sud, 2009, ed. G Duteurtre and B Faye, 117-132. Versailles: Quae.

Ayantunde, AA, J de Leeuw, MD Turner, and M Said. 2011. Challenges of assessing the sustainability of (agro)-pastoral systems. Livestock Science 139: 30-43.

Ba, A, M Lesnoff, R Poccard-Chapuis, and CH Moulin. 2011. Demographic dynamics and off-take of cattle herds in southern Mali. Tropical Animal Health and Production 43: 1101-1109.

Becker, L. 1990. Collapse of the family farm in West Africa? Evidence from Mali. The Geographical Journal 156: 313-322.

Bertaux, D. 1997. Les récits de vie: Perspective ethnosociologique. Paris: Nathan Université.

Bonfiglioli, AM. 1988. Dudal: Histoire de famille et histoire de troupeau chez un groupe Woodabe du Niger. Cambridge University Press. Paris: Ed. de la Maison des Sciences de l'Homme.

Bonfiglioli, AM. 1990. Pastoralisme, agro-pastoralisme et retour: itinéraires sahéliens. Cahier Des Sciences Humaines 26(1-2): 255-266.

Cesaro, J, G Magrin, and O Ninot. 2010. Atlas de l'élevage au Sénégal: commerce et territoires. Paris: Projet de Recherche ICARE.

Chambers, R. 2006. Vulnerability coping and policy (editorial introduction), IDS Bulletin.

Chia, E, P Dugué, and S Sakho-Jimbira. 2006. Les exploitations agricoles familiales sont-elles des institutions? Cahiers Agricultures 15: 498-505.

Corniaux, C, F Vatin, and B Faye. 2006. Herd management and milk rights: Decision-making and dairy production in the Sahel. Cahiers Agricultures 15: 515-522.

De Sardan, JP. 2003. L'enquête socio-anthropologique de terrain: synthèse méthodologique et recommandations à l'intention des étudiants. In Etudes et Travaux $\mathrm{N}^{\circ}$ 13. Niamey: LASDEL.

DeHaan, L, and A Zoomers. 2005. Exploring the frontier of livelihoods research. Development and Change 36: 27-47.

De Haan, A, K Brock, and N Coulibaly. 2002. Migration, livelihoods and institutions: Contrasting patterns of migration in Mali. Journal of Development Studies 38: 37

Dia, D. 2009. Les territoires d'élevage laitier à l'épreuve des dynamiques politiques et économiques: éléments pour une géographie du lait au Sénégal. Dakar: Thesis in Geography; University Cheikh Anta Diop.

Dupire, M. 1996. Peuls Nomades: etude descriptive des wodaabe du sahel nigérien. Paris: Ed. Khartala.

Ellis, F. 2000. The determinants of rural livelihood diversification in developing countries. Journal of Agricultural Economics 51: 289-302.

Grégoire, E, and C Raynaut. 1997. Sahels: diversité et dynamiques des relations sociétés-nature. Paris: Karthala.

Kaufmann, JC. 1996. L'entretien compréhensif. Paris: Nathan.

Lesnoff, M, C Corniaux, and P Hiernaux. 2012. Sensitivity analysis of the recovery dynamics of a cattle population following drought in the Sahel region. Ecological Modelling 232: 28-39.

Little, PD, JG McPeak, CB Barrett, and P Kristjanson. 2011. Challenging orthodoxies: Understanding poverty in pastoral areas of East Africa. Paper: Economics Faculty Scholarship. 83.

Ly, C, A Fall, and I Okike. 2010. West Africa: The livestock sector in need of regional strategies. In Livestock in a changing landscape: Experiences and regional perspectives. Washington, Covelo, London: Island Press.

McPeak, JG, and CB Barrett. 2001. Differential risk exposure and stochastic poverty traps among East African pastoralists. American Journal of Agricultural Economics 83(3): 674-679.

Manoli, C. December 2012. Le troupeau et les moyens de sécurisation des campements pastoraux: Une étude de la gestion des troupeaux de la Communauté Rurale de Tessekre, dans le Ferlo Sénégalais, 244. Dedieu, Moulin: Livestock Science thesis, University of Montpellier.

Manoli, C, and V Ancey. 2014. Effets ambigus de la mobilité des jeunes pasteurs: entre la sécurisation des conditions de vie pastorales et l'émancipation individuelle au Ferlo. In Mobilités et migrations: figures et enjeux contemporains, ed. G Azoulay, V Ancey, D Dormay, C Crenn, A Mangu, and A Thomashausen, 185-201. Paris: L'Harmattan.

Moulin, CH, S Ingrand, J Lasseur, S Madelrieux, M Napoléone, J Pluvinage, and V Thénard. 2008. Comprendre et analyser les changements d'organisation et de conduite de l'élevage dans un ensemble d'exploitations: propositions méthodologiques. In L'élevage en mouvement: flexibilité et adaptation des exploitations d'herbivores, ed. B Dedieu, E Chia, B Leclerc, CH Moulin, and M Tichit, 181-196. Paris: QUAE.

Nozieres, MO, CH Moulin, and B Dedieu. 2011. The herd, a source of flexibility for livestock farming systems faced with uncertainties? Animal 5: 1-16.

Otte, MJ, and P Chilonda. 2002. Cattle and small ruminant production systems in sub-Saharan Africa: A systematic review. Rome: Livestock Information Sector Analysis and Policy Branch, FAO Agriculture Department.

R Development Core Team. 2011. R: A language and environment for statistical computing. Vienna: R Foundation for Statistical Computing. ISBN 3-584 900051-07-0, URL http://www.R-project.org.

Siegmund-Schultze, M, B Rischkowsky, and JM King. 2011. Cattle as live stock: a concept for understanding and valuing the asset function of livestock. Outlook on Agriculture 40: 287-292.

Schneider, HK. 1979. Livestock and equality in East Africa: The economic basis for social structure. Bloomington: Indiana University Press.

Scoones, I. 1995. Living with uncertainty, new directions in pastoral development in Africa, 362. London: IIED.

Schareika, N. 2003. Know to move, move to know: Ecological knowledge and herd movement strategies among the Wodaabe of Southeastern Niger. Rome: FAO Inter-Departmental Working Group on Biological Diversity for Food and Agriculture.

Sutter, JW. 1987. Cattle and inequality: Herd size differences and pastoral production among the Fulani of Northeastern Senegal. Africa 57: 196-218.

Swift, J. 2006. Why are rural people vulnerable to famine? IDS Bulletin 37(4): 41-49.

Thébaud, B. 2002. Foncier pastoral et gestion de l'espace au Sahel: Peuls du Niger oriental et du Yagha burkinabé. Paris: Editions Khartala.

Thébaud, B. 1990. Politiques d'hydraulique pastorale et gestion de l'espace au Sahel. Cahiers Sciences Humaines 26: 13-31.

Thornton, PK, RB Boone, KA Galvin, SB BurnSilver, MM Waithaka, J Kuyiah, S Karanja, E Gonzalez-Estrada, and M Herrero. 2007. Coping strategies in livestock-dependent households in East and southern Africa: A synthesis of four case studies. Human Ecology 35: 461-476.

Van Dijk, H. 1994. Livestock transfers and social security in Fulbe society in the Hayre, central Mali. Focaal 22(23): 97-112.

Wane, A, A Camara, V Ancey, N Joly, and S Ka. 2009. Choix individuel et sécurisation collective: le salariat dans les exploitations pastorales du Ferlo (Sahel sénégalais). Economies et Societes 9: 14-43.

Wane, A, V Ancey, and I Toure. 2010. Pastoralisme et recours aux marchés: cas du Sahel sénégalais (Ferlo). Cahiers Agricultures 19: 14-20.

\subsection{6/2041-7136-4-3}

Cite this article as: Manoli et al:: How do pastoral families combine livestock herds with other livelihood security means to survive? The case of the Ferlo area in Senegal. Pastoralism: Research, Policy and Practice $2014,4: 3$

\section{Submit your manuscript to a SpringerOpen ${ }^{\odot}$ journal and benefit from:}

- Convenient online submission

- Rigorous peer review

- Immediate publication on acceptance

- Open access: articles freely available online

High visibility within the field

- Retaining the copyright to your article

Submit your next manuscript at $>$ springeropen.com 